\title{
Kematian akibat pembunuhan di Kota Manado yang masuk Bagian Forensik RSUP Prof. Dr. R. D. Kandou Manado tahun 2014
}

\author{
${ }^{1}$ Virginia F. Liempepas \\ ${ }^{2}$ Johannis F. Mallo \\ ${ }^{2}$ Nola T.S. Mallo \\ ${ }^{1}$ Kandidat Skripsi Fakultas Kedokteran Universitas Sam Ratulangi Manado \\ ${ }^{2}$ Bagian Ilmu Kedokteran Forensik dan Medikolegal Fakultas Kedokteran \\ Universitas Sam Ratulangi Manado \\ Email: liempepasvirginia@yahoo.com
}

\begin{abstract}
Death caused by murder is an unnatural death case, violates the human right, and should be more concerned by many people. WHO listed 475.000 homicides that occured in 2012 around the world. This study aimed to determine the profile of murder victims at Manado city in 2014 and to get data of homicides that handled by forensic department of RSUP. Prof. Dr. R. D. Kandou Manado in 2014. This was a descriptive retrospective study. Data were obtained retrospectively from the Forensic Department of Prof. Dr. R. D. Kandou Hospital, urban and rural Police Station in Manado city. The results showed that the murdered cases that occured at Manado city in 2014 were 27 cases. The 17 cases listed were autopsied by the Forensic Department meanwhile the 10 cases were not. The most victims were adolescent's aged 12-25 years, 14 cases, 25 of 27 victims are male. Most of the cases were caused by sharp force violence as many as 18 cases. Conclusion: There were 27 murder cases listed that occured at Manado in 2014. 17 cases autopsied and the rest were not. The most victims were adolescent, male and caused by sharp force violence.
\end{abstract}

Keywords: murder, forensic, manado

\begin{abstract}
Abstrak: Kasus kematian akibat pembunuhan merupakan suatu kasus kematian tidak wajar, pelanggaran HAM dan sudah sepatutnya menjadi perhatian banyak pihak. WHO mencatat terjadi 475.000 kasus pembunuhan di dunia tahun 2012. Penelitian ini bertujuan untuk mengetahui profil korban kejahatan pembunuhan di kota Manado tahun 2014 dan untuk mendapatkan data kasus pembunuhan yang masuk di bagian forensik RSUP. Prof. Dr. R. D. Kandou Manado tahun 2014. Penelitian ini bersifat deskriptif retrospektif dengan melakukan peninjauan data yang diambil secara retrospektif di bagian forensik RSUP Prof. Dr. R. D. Kandou Malalayang, Polres dan Polsek Manado. Hasil penelitian memperlihatkan tercatat kasus pembunuhan yang terjadi di Manado selang tahun 2014 sebanyak 27 kasus. 17 kasus di autopsi di bagian forensik, sementara 10 lainnya tidak. Korban terbanyak ada pada kelompok usia remaja (12-25 tahun) 14 kasus, 25 dari 27 korban berjenis kelamin laki-laki. Dan untuk sebab kematian, didapatkan sebab kematian terbanyak 18 kasus pembunuhan dengan kekerasan tajam. Simpulan: Tercatat 27 kasus pembunuhan yang terjadi di kota Manado selama tahun 2014. Tujuh belas kasus dilakukan autopsi dan 10 lainnya tidak. Kelompok usia remaja dan jenis kelamin laki-laki lebih beresiko tinggi menjadi korban pembunuhan dan dengan sebab kematian akibat kekerasan tajam.
\end{abstract}

Kata kunci: pembunuhan, forensik, Manado

Semua makhluk hidup akan mengalami siklus kehidupan, termasuk manusia akan melewati proses pembuahan, kelahiran, kehidupan di dunia, dan diakhiri dengan 
kematian. Kematian adalah kegagalan dari tubuh sebagai suatu sistem yang terintegrasi yang berhubungan dengan kehilangan yang menetap dari sistem respirasi dan persarafan. Tetapi saat ini definisi kematian yang sudah diterima secara umum ialah kematian batang otak. Jika area ini mati, maka orang tersebut tidak akan bisa bernapas secara spontan atau sadar kembali. ${ }^{1}$

Kematian adalah hal yang tidak bisa dihindari oleh setiap makhluk hidup, dapat terjadi kapan saja, dimana saja, dengan banyak penyebab. Ada banyak sekali halhal yang dapat menyebabkan seseorang kehilangan kehidupannya. World Health Assembly XX tahun 1967 mendefinisikan penyebab kematian adalah penyakit, keadaan sakit atau cedera yang dapat menimbulkan kematian dan kecelakaan atau kekerasan yang menimbulkan cedera yang mematikan. ${ }^{2}$

Menurut Undang-Undang Republik Indonesia Nomor 36 Tahun 2009 Tentang Kesehatan, Pasal 117: "Seseorang dinyatakan mati apabila fungsi sistem jantung, sirkulasi dan sistem pernafasan terbukti telah berhenti secara permanen, atau apabila kematian batang otak telah dapat dibuktikan. ${ }^{3}$

Pembunuhan berasal dari kata dasar bunuh yang menurut KBBI adalah menghilangkan (menghabisi; mencabut) nyawa. ${ }^{4}$ Ada banyak cara dan metode pembunuhan yang kerap kali terjadi di masyarakat saat ini. Tindak kriminal pembunuhan tentu saja telah melanggar HAM yang dalam UU No.39 tahun 1999 tentang HAM mencatat bahwa hak asasi manusia merupakan hak dasar yang secara kodrati melekat pada diri manusia, bersifat universal dan langgeng, oleh karena itu harus dilindungi, dihormati, dipertahankan, dan tidak boleh diabaikan, dikurangi, atau dirampas oleh siapapun. ${ }^{3}$

WHO mencatat terjadi 475.000 kasus pembunuhan di dunia tahun 2012 (6,7/100.000 populasi), dimana $60 \%$ korban adalah laki-laki dengan rentang usia 15-44 tahun. ${ }^{5}$ Tahun 2013, Polda Metro Jaya mencatat ada 51.444 kasus kriminal di
Jakarta dan sekitarnya, atau satu kejahatan tiap 10 menit 13 detik. Pembunuhan 74 kasus, naik 2 kasus (3\%) dari tahun 2012. Angka kejahatan yang terbilang cukup besar. 6 Sementara di Sulawesi Utara, menurut data Polda, angka kriminalitas Januari-Mei 2014 mencapai 4828 kasus, sedangkan Januari-Mei 2015 ada 5165 kasus yang dilaporkan. Aksi kriminalitas yang paling dominan tahun 2014 adalah penganiayaan berat (368 kasus), narkoba/miras (338 kasus), KDRT (84 kasus), diikuti kasus Curat (20), Curas (17), pemerkosaan (15), pembunuhan (14), tarkam (10) dan lain-lain. ${ }^{7}$ Di Manado sendiri, tercatat terjadi 13 kasus pembunuhan tahun 2012 dan 19 kasus pembunuhan terjadi selama tahun 2013. ${ }^{8}$

Ilmu kedokteran forensik dan medikolegal mempunyai peranan penting dalam mengungkap kasus terjadinya suatu kematian dengan melakukan pemeriksaan medik untuk tujuan membantu penegakan hukum, baik untuk korban hidup maupun korban mati. Ilmu kedokteran forensik didefinisikan sebagai cabang ilmu kedokteran yang menerapkan pengetahuan medis dan paramedis untuk kepentingan penyelesaian perkara dalam pengadilan (pre justitia).

Pemeriksaan medik untuk tujuan membantu penegakan hukum antara lain adalah pembuatan visum et repertum terhadap seseorang yang diduga sebagai korban suatu tindak pidana, baik dalam peristiwa kecelakaan lalu lintas, kecelakaan kerja, penganiayaan, pembunuhan, dan pemerkosaan. ${ }^{9}$ Berikut ini beberapa peran ilmu kedokteran forensik:

1. Pemeriksaan di tempat kejadian perkara

Bilamana pihak penyidik mendapat laporan bahwa suatu tindak pidana yang mengakibatkan kematian korban telah terjadi, maka pihak penyidik dapat meminta/memerintahkan dokter untuk melakukan pemeriksaan di TKP tersebut sesuai dengan Hukum Acara Pidana yang berlaku dan sesuai pula dengan UU Pokok Kepolisian tahun 1961 no.13 pasal 13 atau sesuai dengan ketentuan pasal 3 Keputusan MenHanKam/Pengab/ 
No.Kep/B/17/VI/1974.

Kesimpulan yang dapat diambil dari pemeriksaan di TKP dimana pihak penyidik dan dokter bahu-membahu dalam menangani kasus yang dihadapi adalah:

- Membantu mempercepat proses penyidikan

- Membantu mengarahkan tindakan atau pemeriksaan yang akan dilakukan selanjutnya: orang-orang yang perlu dimintakan keterangan, senjata atau alat bukti yang perlu dicari, pemeriksaan laboratorium yang perlu dilakukan dan lain sebagainya.

- Memberikan pelayanan kepada masyarakat yang baik, dalam hal waktu, personalia serta biaya. ${ }^{10}$

2. Pembuatan Visum Et Repertum

Visum Et Repertum (VeR) adalah keterangan yang dibuat oleh dokter atas permintaan penyidik yang berwenang mengenai hasil pemeriksaan medik terhadap manusia, baik hidup atau mati, ataupun bagian atau diduga bagian dari tubuh manusia, berdasarkan keilmuan dan dibawah sumpah, untuk kepentingan peradilan. VeR adalah salah satu alat bukti sah dalam peradilan berdasarkan pasal 184 KUHAP. $^{11}$

\section{Autopsi}

Autopsi adalah pemeriksaan terhadap tubuh mayat yang meliputi pemeriksaan luar atau pemeriksaan dalam dengan tujuan menemukan proses penyakit dan/atau adanya cedera, serta melakukan interpretasi dan mencari hubungan atas penemuan tersebut untuk menerangkan penyebab kematian serta mencari hubungan antara kelainan yang ditemukan dengan penyebab kematian. ${ }^{12}$

\section{METODE PENELITIAN}

Penelitian ini menggunakan metode deskriptif retrospektif. Pada penelitian ini dilakukan peninjauan data yang diambil secara retrospektif di Bagian Forensik RSUP Prof. Dr. R. D. Kandou Malalayang, Polres dan Polsek Manado. Populasi penelitian ini ialah kasus pembunuhan dengan korban meninggal dunia di Manado selama tahun 2014. Hasil yang didapatkan dikelompokkan berdasarkan variabel jumlah kasus, usia korban, jenis kelamin dan sebab kematian.

\section{HASIL PENELITIAN}

Dari penelitian secara retrospektif yang telah dilakukan di bagian Forensik RSUP Prof. Dr. R. D. Kandou Malalayang, Polres dan Polsek Manado tentang kasus pembunuhan yang terjadi selama periode tahun 2014, didapatkan 27 kasus pembunuhan yang terjadi di kota Manado, Sulawesi Utara.

Berdasarkan data yang dikumpulkan dari Polres dan 13 polsek yang ada di kota Manado, jumlah kasus pembunuhan di kota Manado tahun 2014 sejumlah 19 kasus, dimana tercatat 14 kasus di autopsi dan 5 kasus tidak di autopsi. Sedangkan berdasarkan data yang diambil dari buku register di bagian Forensik RSUP Prof. Dr. R. D. Kandou Malalayang, tercatat terdapat 17 kasus pembunuhan di kota Manado tahun 2014 yang di autopsi di bagian Forensik RSUP Prof. Dr. R. D. Kandou. Setelah digabungkan, jumlah kasus pembunuhan di kota Manado pada tahun 2014 berdasarkan data buku register di bagian Forensik RSUP Prof. Dr. R. D. Kandou Malalayang, Polres dan Polsek Manado, tercatat ada 27 kasus pembunuhan yang terjadi, 17 kasus diantaranya di autopsi sedangkan 10 lainnya tidak dilakukan autopsi.

\section{घ Autopsi $\square$ Tidak Autopsi}

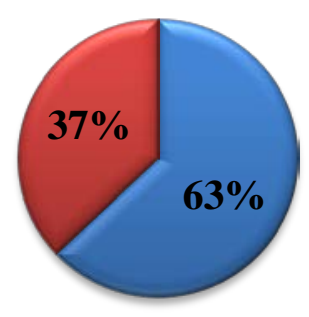

Gambar 1. Diagram kasus pembunuhan di kota Manado tahun 2014 yang di autopsi dan tidak di autopsi. 
Berdasarkan data usia, korban pembunuhan terbanyak ada di kelompok usia remaja (12-25 tahun), 14 kasus dengan persentase 51,9\%, diikuti kelompok usia dewasa 10 kasus dengan persentase 37,0\%. Kelompok usia lansia didapatkan 1 kasus (persentase 3,7\%). Sedangkan pada kelompok usia balita (0 - 5 tahun) dan manula ( $>65$ tahun) tidak didapatkan kasus, tetapi terdapat 2 kasus yang data usianya tidak tecantum (Gambar 2).

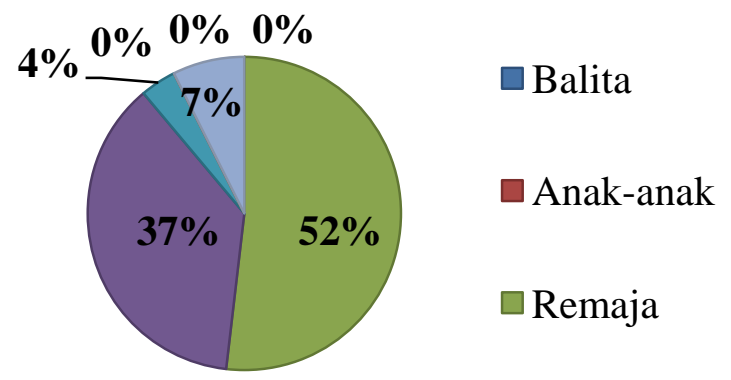

Gambar 2. Diagram Kasus Pembunuhan di Kota Manado Tahun 2014 Berdasarkan Kelompok Usia

Korban pembunuhan terbanyak di kota Manado pada tahun 2014 berjenis kelamin laki-laki dengan jumlah 25 korban (92,6\%) dan jenis kelamin perempuan hanya 2 korban (7,4\%) (Gambar 3).

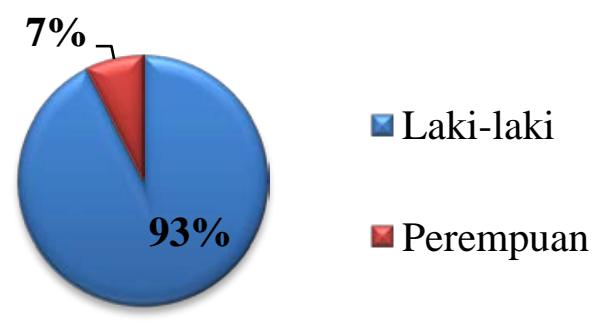

Gambar 3. Diagram Kasus Pembunuhan di Kota Manado Tahun 2014 Berdasarkan Jenis Kelamin

Kekerasan tajam mendominasi sebab kematian kasus pembunuhan yang terjadi di Kota Manado tahun 2014, sebanyak 18 kasus dengan persentase 66,7\%. Kejadian sebab kematian akibat kekerasan tumpul tercatat sebanyak 3 kasus $(11,1 \%)$ dan sisa
6 kasus lainnya tidak terdapat data yang lengkap.

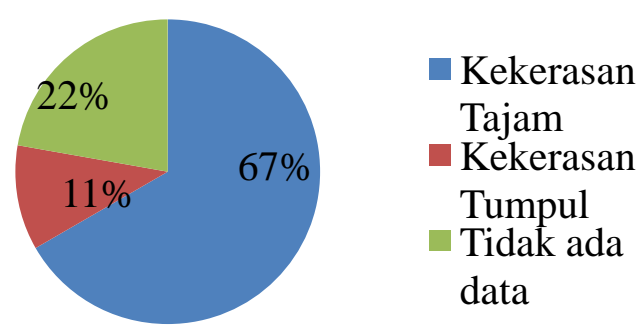

Gambar 4. Diagram Kasus Pembunuhan di Kota Manado Tahun 2014 Berdasarkan Sebab Kematian

\section{BAHASAN}

Dari hasil penilitian deskriptif retrospektif yang dilakukan di bagian forensik RSUP Prof. Dr. R. D. Kandou Malalayang, Polres dan Polsek Manado didapatkan data kematian akibat pembunuhan di kota Manado tahun 2014 yang masuk di bagian Forensik RSUP Prof. Dr. R. D. Kandou Malalayang.

Kasus pembunuhan di kota Manado tahun 2014 berdasarkan data yang dikumpulkan di Polres dan di 13 Polsek yang ada di kota Manado sebanyak 19 kasus. Dari 19 kasus pembunuhan yang didapatkan, menurut keterangan pihak kepolisian 14 diantaranya dilakukan autopsi, sementara 5 kasus lainnya tidak dilakukan autopsi. Hal ini tidak sesuai dengan keterangan dari Polres Manado yang menyebutkan bahwa kasus pembunuhan yang terjadi selama tahun 2014 di kota Manado sebanyak 27 kasus. Keterbatasan peneliti dalam pengumpulan data dan tidak lengkapnya data yang diberikan pihak kepolisian menjadi faktor utama adanya ketidaksesuaian data kasus pembunuhan yang diperoleh.

Banyaknya kasus kematian akibat pembunuhan yang di autopsi di bagian forensik RSUP Prof. Dr. R. D. Kandou Malalayang selama tahun 2014 berdasarkan buku data register yang ada di bagian Forensik rumah sakit. Dari 27 kasus pembunuhan yang terjadi di kota Manado tahun 2014, 17 kasus tercatat masuk untuk 
di autopsi.

Setelah data yang didapatkan di Polres, Polsek dan di bagian Forensik RSUP Prof. Dr. R. D. Kandou Malalayang digabungkan, data yang berhasil dikumpulkan sebanyak 27 kasus pembunuhan yang terjadi di tahun 2014. Data ini sudah sesuai dengan data jumlah kasus pembunuhan yang ada di Polres Manado. Data ini juga menunjukkan kasus pembunuhan di kota Manado meningkat selang 3 tahun dari tahun 2012 sebanyak 13 kasus, 19 kasus tahun 2013 dan 27 kasus tahun 2014. ${ }^{8}$ Setelah digabungkan, didapatkan dari 27 kasus kematian 17 kasus tercatat di bagian forensik RSUP Prof. Dr. R. D. Kandou Malalayang untuk di autopsi, sementara 10 lainnya tidak. Jika dipersentasekan kasus yang di autopsi sekitar 63\% dan kasus pembunuhan yang tidak di autopsi sekitar 37\%. Berdasarkan keterangan dari kepolisian, ada beberapa hal yang menyebabkan mayat/jenazah tidak di autopsi, diantaranya karena kasus tersebut adalah jelas tindak pidana pembunuhan dan pelaku telah tertangkap, penolakan dari pihak keluarga karena keterbatasan biaya dan ada juga karena jenazah dikirim ke luar daerah.

Berdasarkan pembagian kelompok usia, korban pembunuhan terbanyak ada di kelompok usia remaja (12-25 tahun), 14 kasus dengan persentase $51,9 \%$, diikuti dewasa (26 - 45 tahun) 10 kasus dengan persentase $37,0 \%$ dan lansia (46 - 65 tahun) sebanyak 1 kasus. Sedangkan pada kelompok usia balita ( 0 - 5 tahun), anakanak (6 - 11 tahun) dan manula (> 65 tahun) tidak didapatkan kasus. Data ini terdapat kekurangan karena 2 kasus diantaranya memiliki data usia yang tidak lengkap. Walaupun demikian, korban pembunuhan terbanyak ada di kategori usia remaja dan dewasa (12-45 tahun), data ini serupa dengan data WHO tahun 2012 yang menyebutkan korban pembunuhan terbanyak 60\% laki-laki dengan rentang usia 15-44 tahun. ${ }^{5}$ Perkembangan emosi remaja hingga dewasa menunjukkan sifat sensitif, reaktif dan tempramental (mudah tersinggung, marah, sedih). Pada kategori usia ini juga, terlebih remaja, rasa ingin diterima, ingin dihargai, dan menunjukkan kehebatan lebih meningkat. Faktor psikologis seperti ini yang akhirnya memicu terjadinya rasa tidak suka, marah bahkan demdam dari orang lain yang dapat mengakibatkan terjadinya satu tindak kriminalitas.

Data yang dibagi berdasarkan jenis kelamin korban, didapatkan dari 27 korban meninggal 25 diantaranya adalah korban berjenis kelamin laki-laki dan hanya 2 korban berjenis kelamin wanita. Berdasarkan data ini, jenis kelamin lakilaki lebih beresiko tinggi menjadi korban pembunuhan. Data yang dipublikasikan WHO tahun 2012 juga menyebutkan 60\% kasus pembunuhan di dunia dialami oleh laki-laki. $^{7}$

Data berdasarkan sebab kematian, dapat dilihat bahwa kekerasan tajam mendominasi sebab kematian kasus pembunuhan yang terjadi di Kota Manado tahun 2014, sebanyak 18 kasus dengan persentase $66,7 \%$. Kejadian sebab kematian akibat kekerasan tumpul tercatat sebanyak 3 kasus (11,1\%) dan sisa 6 kasus lainnya tidak terdapat data yang lengkap. Kekerasan tajam dapat mengakibatkan luka iris/sayat, luka tusuk dan luka bacok yang berpeluang besar mengakibatkan kematian. Selain itu sumber kekerasan tajam seperti pisau, panah wayer, dan benda tajam lainnya bukan barang yang susah didapat, berbeda dengan luka akibat senjata api, trauma fisika ataupun trauma kimia.

\section{SIMPULAN}

Tercatat 27 kasus pembunuhan yang terjadi di kota Manado selama tahun 2014. Tujuh belas kasus dilakukan autopsi dan 10 lainnya tidak. Kelompok usia remaja dan jenis kelamin laki-laki lebih beresiko tinggi menjadi korban pembunuhan dan dengan sebab kematian akibat kekerasan tajam.

\section{DAFTAR PUSTAKA}

1. Oeiyano B, Siwu J, Mallo J. Temuan autopsi pada kematian mendadak akibat penyakit sistem pernapasan. [skripsi]. [Manado]: Universitas Sam 
Ratulangi; 2012.

2. Australian Instituteof Health and Welfare. Multiple causes of death: an analysis of all natural and selected chronic disease causes of death 19972007 (online version). 17 November 2015 [diakses 01/12/15]. Tersedia di: http://www.aihw.gov.au/multiplecauses-of-death/introduction/.

3. Majelis Permusyawaratan Rakyat RI. UUD Negara Republik Indonesia tahun 1945. Sekretariat Jendral MPR RI; 2007

4. Badan Pengembangan dan Pembinaan Bahasa. Kamus besar bahasa Indonesia. Edisi ke-3. Departemen Pendidikan dan Kebudayaan; 2005.

5. WHO, Global Health Observatory (GHO) Data. Violence Prevention. 2014. [diakses 17/09/15]. Tersedia di: http://www.who.int/gho/violence/en/

6. Detik News. Tahun politik, polda Metro prediksi kejahatan akan meningkat. 29 Desember 2013. [diakses 17/09/15]. Tersedia di: http://news.detik.com/berita/2453263/ tahun-politik-polda-metro-prediksikejahatan-di-2014-akan-meningkat.

7. Cybersulutnews. Kriminalitas Meningkat di Sulut, Aksi Penganiayaan Berat
Mendominasi. 18 Juni 2015. [diakses 17/09/2015]. Tersedia di: http://cybersulutnews.co.id/kriminalit as-meningkat-di-sulut-aksipenganiayaan-berat-mendominasi/

8. Metro. 31 Desember 2013, 2013, 19 Kasus Pembunuhan Terjadi di Manado. [diakses 17/09/2015]. Tersedia di: http://harianmetro.co.id/index.php/tin dakan-kriminal/12745-2013-19kasus-pembunuhan-terjadi-di-manado

9. Bagian Kedokteran Forensik FK-UI. Ilmu Kedokteran Forensik. Jakarta;1997. h.5.

10.Idries AM, Tjiptomartono AL. Penerapan Ilmu Kedokteran Forensik dalam Proses Penyidikan. Edisi revisi. Jakarta : Sagung Seto; 2008. h.9-12, 37, 50-1,

11.Venita, Safitry O. Prosedur medikolegal dan Visum et Repertum. Di: Tanto Ch, Liwang Fr, Hanifati S, Pradipta EA, editor. Kapita Selekta Kedokteran. Edisi Ke-4. Jakarta: Media Aesculapius; 2014. h.869-70.

12.Venita, Safitry O. Autopsi. Di: Tanto Ch, Liwang Fr, Hanifati S, Pradipta EA, editor. Kapita Selekta Kedokteran. Edisi Ke-4. Jakarta: Media Aesculapius; $2014 . \quad$ h.874- 